\title{
REFUGEE HEALTH: A GENDER COMPARISON IN HEALTH CARE ACCESS
}

\author{
by
}

Kate E. Dadey, BA Sociology with Distinction, University of Windsor, 2007

\author{
A Major Research Paper \\ presented to Ryerson University \\ in partial fulfilment of the requirements for the degree of \\ Master of Arts \\ in the Program of \\ Immigration and Settlement Studies
}

Toronto, Ontario, Canada, 2008

(C) Kate E. Dadey 2008 


\section{Author's Declaration}

I hereby declare that I am the sole author of this major research paper.

I authorize Ryerson University to lend this paper to other institutions or individuals for the purpose of scholarly research.

Signature

I further authorize Ryerson University to reproduce this paper by photocopying or by other means, in total or in part, at the request of other institutions or individuals for the purpose of scholarly research.

Signature 


\title{
REFUGEE HEALTH: A GENDER COMPARISON IN HEALTH CARE ACCESS
}

(C) Kate E. Dadey 2008

\author{
Master of Arts \\ Immigration and Settlement Studies \\ Ryerson University
}

\begin{abstract}
Research suggests that Canada's newly arrived immigrant and refugee communities tend to be healthier than the domestic population and that their health declines over time. Studies examining immigrant and refugee health primarily focus on how barriers associated with language, the settlement experience, culture, and systemic processes impede the utilization of health services among refugee men and women respectively. However, without the benefit of a gender comparison, such studies fail to identify the variation in health needs and differences in health-seeking between refugee men and women, and are thus limited in their capacity to improve service utilization. Drawing from existing literature on refugee health status premigration and during resettlement, this paper implicates the role of health care reform processes in exploring the gender differences in access and health-seeking. A postcolonial feminist epistemology is advanced as a means to include the voices of refugees and other marginalized groups in future research and practice in order to encourage substantive change.
\end{abstract}

Key words: refugee health, gender, health care reform, anti-oppression, postcolonial feminism 


\section{Acknowledgements}

I am extremely grateful to my mother Gertrude Godwin for her moral support, encouragement and the insightful discussions, which facilitated my selection of refugee health as the topic for this research paper. My gratitude also extends to my grandmother Kate Annor who was among the pioneer teachers in Africa during a time when women's place was thought to be exclusively in the home. I am also very thankful to my great grandmother Felicia whose unconditional love, nurturing, strength and guidance instilled in me courage, humility, and strong work ethic that has enabled me achieve academic success, particularly throughout my post-secondary career.

Lastly, I thank Dr. June Yee for her unwavering commitment to my supervision. Dr. Yee has been a great mentor who showed a sincere interest in my research, and has diligently guided me throughout the writing process. I also thank Dr. Gordon Pon for his willingness to assist in editing my work. 


\section{Table of Contents}

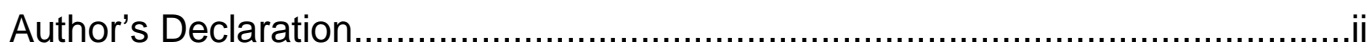

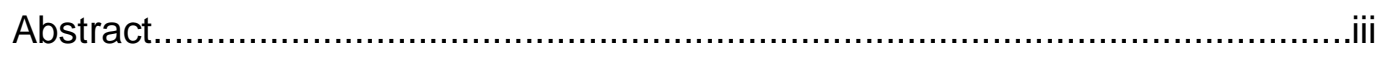

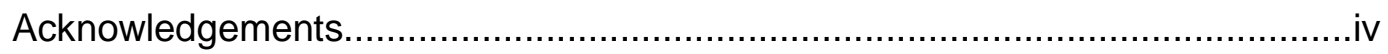

Contextualizing Refugee Health: An Introduction....................................

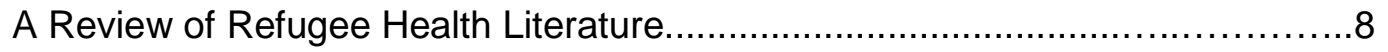

The Historical Oppression of Racialized Minority Newcomers: A Theoretical

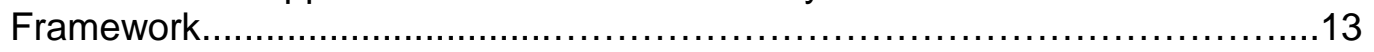

Canadian Health Care: A Question of Universality.....................................19

Gender Differences in Health-Seeking Behaviour......................................25

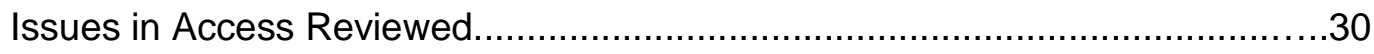

Towards a Postcolonial Feminist Scholarship of Refugee Health....................34

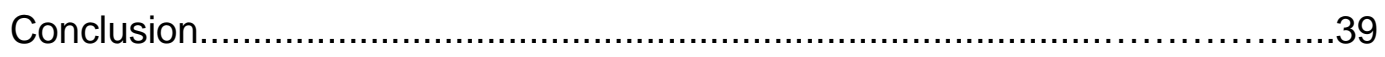

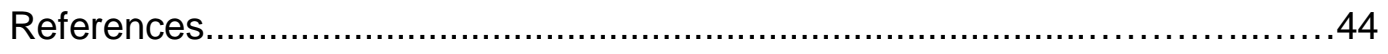




\section{Contextualizing Refugee Health: An Introduction}

Migration and health are assuming a new significance and posing new challenges to many countries around the world. With growing global inequality, increased state militarization and the many civil and political crises worldwide (Tolentino, 1996; Goldstein \& Whitworth, 2005), a large number of people have been scattered within and across the borders of many nation states. Pavlish (2007) defines refugees as

“...people who have left their usual place of residence and crossed an international border because of persecution [based on race, religion, nationality, political opinion, and membership in a particular social group], armed conflict or violence", and owing to these reasons are unwilling to return to their country of origin (p. 28).

The forced nature of refugee migration holds implications for the health and well being of men and women alike.

Of the 21 million displaced people worldwide, the United Nations High Commissioner for Refugees (2005b) estimates that 9.9 million are refugees. Many theories of international migration attempt to explain the motivations and factors that inform migrants' decision to emigrate; where migrants choose to go; and, how forced migration and the refugee experience fits into this framework (Malmberg, 1997). Yet the link between globalized economic development, underdevelopment and a nation's domestic peace cannot be denied (Hegre, Ostby \& Raleigh, 2007, p. 2).

Poverty does not only cause individual insecurity, it also contributes to the broader political instability of a country. Moreover, the roots of rebellion usually have a firmer footing in poorer countries than in wealthier states (Hegre et al., 2007). It thus can be argued that the global refugee crisis is the result of the social, political, and economic disparities between the North and South caused by the hegemonic control wealthy states and corporations in the North have over 
world's resources and the domestic economies of Southern nations; and the continual power struggle for political and economic sovereignty of individual nation states.

Despite some differences in the gender composition of refugees scattered between and among regions and countries, the worldwide percentage of male and female refugees is almost identical (UNHCR, 2000a). The culturally constructed concept of gender refers to the roles and responsibilities attached to the male and female sex categories. Gender is a determinant of health and needs to be considered when examining health disparities.

Because of the existence and reproduction of institutionalized gender hierarchies, women are usually classified as vulnerable, and are described as occupying a subordinate position in many societies worldwide. This consideration for the status of women is reflected in research, policies and programs that focus on Third world women's experiences of inequality, crisis, displacement, and their reproductive health. The plight of women, as well as children displaced by conflict and poverty has been widely documented (Anderson, 2000b; Taft \& Baird, 2004; Spitzer, 2005).

Women and children account for roughly 80 percent of the global refugee population and more than 70 percent of the global poor (UNHCR, 2000a; United Nations Population Fund, 2005). Men, however, have not been exempt from this global system of oppression. The same economic and market forces that enable wealthy countries to control less wealthy nations, also impacts the status of men in the poorer nations of the global South. Widespread unemployment, poverty, and the resultant armed revolutionary struggles over resources further unsettle the social, cultural, political and economic conditions of many developing countries. 
With no alternative options, men are usually recruited into rebel factions or are killed (Hegre et al., 2007; Pavlish, 2007). However, research focusing on the experience of refugee men is minimal. What is also most uncommon in the refugee health literature is a gender comparison of the experiences of refugee men and women.Importantly, most women and some men are vulnerable to the poverty and marginalization of economic restructuring, armed conflict, and the challenges of displacement and resettlement (Spitzer, 2005; Pottie, Brown \& Dunn, 2005).

In this paper, the word health denotes "a state of complete physical, mental, and social wellbeing and not merely the absence of disease or infirmity," (Preamble to the Constitution of the World Health Organization). Refugee health should thus be considered in the broader framework encompassing one's gender, the economic and political situation in the home country; the circumstances of flight within and across national borders; their protracted stay in refugee camps; the dislocation of family members, and the kind of assistance provided to asylum seekers in the third country.

Countries that are signatories of the 1951 United Nations Geneva Convention on the Status of Refugees accept refugees and asylum seekers, and bear the responsibility for protecting the refugee's rights, including their health and welfare (Allotey \& Reidpath 2003; Beiser, 2005b). The non-binding nature of the Convention results in a diffused sense of responsibility and irregular contributions by many nations in the global community. While some less wealthy nations provide temporary asylum and support for refugees, other wealthier nations can afford more permanent resettlement opportunities.

Yet developing countries with fewer economic resources than the major industrialized nations typically host larger numbers of refugees. Approximately 90 
percent of refugees fleeing conflict seek refuge in neighbouring developing nations, while only an estimated 3 percent of refugees and asylum seekers are permitted entry into the nations of the West (Amnesty International Canada, 2008). The unequal distribution of refugees globally holds implications for the welfare and health of refugees. For developing countries, economic restructuring programs (e.g. structural adjustment programs) have led to the reduction of funds for health and social services. Therefore, the humanitarian commitment towards refugees can overburden an already weak system. Nevertheless, within the confines of refugee camps, protected persons can access some health services provided by international aid organizations (Allotey \& Reidpath, 2003).

The issue of access is also central to the refugee health discourse in many countries of permanent resettlement. Governments and policy makers in industrialized countries, such as the United States, Australia, Canada, Denmark, Finland, Netherlands, New Zealand, Norway and Sweden, grapple with balancing their international humanitarian obligations with domestic pressures associated with the long-term resettlement of refugees. Research points to the fact that refugees encounter barriers when accessing health care and social services in countries of resettlement (Association of Local Public Health Agencies-ALPHA, 2003; Agnew, 2002; Pottie et al., 2005; Stampino, 2007). My research will focus on the issues of access encountered by Canada's refugee population. More specifically, this paper will attempt to examine the extent to which being a refugee, male or female affects one's health status, health seeking, and access to health care.

The health status and outcomes of refugees in Canada is distinct from that of other migrant groups, and the native-born population (Allotey \& Reidpath, 2003; Beiser, 2005b; Spitzer, 2005). Unlike other classes of migrants who 
somewhat voluntarily emigrate in search of labour opportunities, refugees are fleeing for their lives and generally arrive in resettlement countries materially and economically destitute. What is more, prior to migration, some refugees lived in refugee camps for protracted periods of time, and others may have experienced torture and trauma (Adams, Gardiner \& Assefi, 2004; Schweitzer, Melville, Steel \& Lacherez, 2006).

Canada's refugee intake fluctuates between 10 to 14 percent of the annual immigration quota. There are two components to Canada's refugee program, namely, the refugee resettlement from abroad program, which involves the Canadian government selecting, sponsoring, and resettling refugees from abroad; and the in-Canada refugee determination system, which allows refugees or otherwise known as protected persons to claim asylum from within Canada (Citizenship and Immigration Canada, 2005; Dench, 2006).

In 2005, Canada admitted 35,768 refugees mainly from Sudan, Ethiopia, Democratic Republic of Congo, Colombia, Afghanistan, Sri Lanka, China, Pakistan, India, and Turkey (CIC, 2005). While some refugees arrive alone, many female refugees arrive with children. Although Canada's immigration policy outlines family reunification as a key objective, certain stipulations and deadlines (e.g. the one year window) associated with application may restrict the reunification of refugee families (Dench, 2006).

Of the number accepted in 2005, 14.5 percent were men and 12.8 percent were women. These figures do not reveal the proportion of people who claimed and were granted refugee status from within Canada. Considering the gender inequality that exists in many developing societies, men may be more educated, fiscally better- off to afford travelling, and may speak English or French, thereby ameliorating their chance of meeting Canada's settlement entry 
requirements (CIC, 2005; UNFPA, 2005). The statistical difference in the gender composition may be the result of more men claiming refugee status from within Canada (Boyd, 1994).

Knowing the number of people who filed and were granted asylum from within the country explains why refugees encounter barriers to accessing and utilizing health services, as only refugees who have been granted the status of protected persons by Canada's Immigration and Refugee Board (IRB) can access social services. Even though Canada is internationally renowned for its commitment to social justice, universal health care and equity, these principles are being challenged as the movement towards reform gains momentum. Social service, health and other government institutions have been slow in changing to meet the needs of diverse newcomer populations.

Refugees face several barriers when accessing health care and other social services. Some such barriers include the lack of awareness of available health services, culture, language, regionalization, ethno-racial discrimination, and the three-month waiting period, as well as the limitations of the Interim Federal Health Plan in the case of government-sponsored refugees (ALPHA, 2003, p. 3; Stewart, 2003). Because of a three-month waiting period for government-assisted refugees, they cannot access health services until after being in the country for ninety days. The Canadian government has tried to bridge this gap with the Interim Federal Health Plan, which provides-government sponsored refugees with limited access to health services. However, asylum seekers who are awaiting refugee determination from the IRB are exempt from this program and cannot access government funded social services until the determination is favourably finalized. 
Notwithstanding selective immigration policies that mandate the medical screening of refugees for communicable diseases (e.g. tuberculosis, leprosy, and HIV), many refugees may arrive with pre-existing physical and mental health problems that are not diagnosed during the pre-migration screening (Adams et al., 2004; Beiser, 2005b). Post arrival, refugees are also susceptible to chronic disease categories that are common in the industrialized world (e.g. heart disease, cancer, diabetes, and high blood pressure) (Meade \& Earickson, 2000; Gatrell, 2002).

The process of immigrant self-selection is also captured in research suggesting the existence of a "healthy immigrant effect" as recent immigrants, despite their country of origin, have been found to be healthier than Canada's national population. However, the health of newcomer populations has also been found to decline over time (Agnew, 2002; Barnes, Harrison \& Heneghan, 2004b; Beiser, 2005b; Newbold, 2005b). Causal factors such as changes in lifestyle and diet, the pressures of poverty, marginalization, systemic inequality and other stresses of resettlement affect the health of newly arriving migrants like refugees.

The Western notion of masculinity identifies physical strength, power, superiority, isolation, and self-reliance as major features of the male role (Courtenary, 2004; Pottie et al., 2005). Even though there are slight cultural variations in gender norms and expectations, studies by Nghe, Mahalik and Lowe (2003), Pottie et al. (2005), Pavlish (2007), and Macnaughton (2008) note that men from the developing world share similar notions of masculinity. Men are expected to prove their manhood by rejecting health beliefs and behaviours that are believed to be feminine (Courtenay, 2000, 2004; Pottie et al., 2005). 
Refugee men's gender socialization influences their views about health. Despite the fact that slightly more refugee men are resettled in Canada, they are more likely to be reluctant in seeking health services (Pottie et al., 2005). The refugee experience of persecution and violence pre-migration, the systemic challenges of social and economic settlement, coupled with the decline in power and status experienced by some refugee men upon resettlement impacts their health-seeking behaviour, and results in the underutilization of health services. A true consideration of refugee men's experience when accessing health services is further distorted by an institutionalized gender bias that is formally thought to benefit all men, but actually favours wealthy men over less privileged racialized men from the Third World.

In this paper, I draw on existing literature on refugee health prior to migration and during resettlement to examine and attempt to answer the following question: To what extent does refugee men's experience of the health care system differ from that of refugee women? While there is extensive research on refugee health and the experiences of refugee women and men respectively, very few scholars have compared refugee men and women's experience of access in health services.

\section{A Review of Refugee Health Literature}

Canada has seen a shift in the source countries of migrants, from traditionally European states to non-European developing nations. Canada's social institutions have been slow in reflecting the societies' cultural, ethno-racial and linguistic diversity. Stampino (2007) suggests that, "[the] different composition of today's immigrants has an impact on access to care..." (p.15). 
Lack of immigrant or refugee-sensitive policy initiatives at the institutional level translate into challenges and barriers for newcomers to Canada who may not understand the cultural norms and expectations of the mainstream, who may not speak English or French, and who may not have legal status. To enable change, research and information about underserved populations are important to health care providers, and facilitate a reasonable understanding of refugee health (Beiser, 2005b).

Health implies a state of complete physiological and social wellbeing, and scholars from various backgrounds including geography, medicine, nursing, and the social sciences have contributed to the body of research in the field of refugee health. Most often, it is the health scientists who, typically espouse a positivist orientation, have written much of the refugee health literature. It is also the health care professionals, such as Fowler (1998), Beiser (2005b), Beiser \& Stewart (2005c), and Lasser, Himmelstein \& Woolhandler (2006) who have conducted studies focusing on the health status and the long-term health and well being of refugees pre-migration and the challenges they encounter during the resettlement process. Yet the positivist orientation of such studies homogenizes refugee populations and lead to the construction of stereotypes and generalizations, as the patients' individuality, and the socio-economic and political influences that could affect their health are ignored.

Research on the health of resettled refugees has focused on their pre and post migration health status, as well as the chronic diseases that may be diagnosed once resettled in the country of asylum (Dunn \& Dyck, 2000; Perez, 2002; Adams et al., 2004; Ali, McDermott \& Gravel, 2004; Beiser, 2005b; Newbold, 2005b). Prior to migration, refugee health is compromised in home countries and in refugee camps (Adams et al., 2004; Schweitzer et al., 2006). 
According to Adams et al. (2004), while refugees seek safety in camps, "continued interethnic strife, sexual violence, and disease epidemics [within the camps] often perpetuate the dangerous environment from which people fled" ( $p$. 1548). Refugees lack human agency when it comes to their health and living conditions.

The experience of trauma affects the physical, mental and emotional health of refugees post migration as evidenced in higher "levels of posttraumatic stress, anxiety and depression" (Schweitzer et al., 2006, p. 179). Although research (Newbold, Eyles, Birch, \& Spencer, 1998a; Ali et al., 2004; Besier, 2005b; Beiser \& Stewart, 2005c; Newbold, 2005b) has found immigrants to be healthier than Canada's national population, immigrants and refugees are also more likely to transition to poor health because of the economic and social barriers they encounter during settlement and resettlement respectively.

In analyzing studies on health inequalities, it is crucial to consider how health care restructuring policies have affected the health of underserved populations. In their article, Newbold and his colleagues indicate that although Canada has a publicly funded health care system, these funds are allocated among service providers based on the level of service provided instead of the needs of the population being served (Newbold et al., 1998a).

Similarly, Lynam (2003) and her colleagues suggest that within the Canadian context, fiscal restraint policies have affected both nurses and patients, and have created inequalities in health care delivery, which impacts more vulnerable and marginalized populations (Lynam, Henderson, Browne, Smye, Semeniuk, Blue, Singh, \& Anderson, 2003, p. 112). These studies are useful since they uncover how resources for health care are allocated and the extent to which the needs of the population are factored into the allotment equation. 
Another area that has received extensive research consideration is the issue of equity of access. In recent years, federal, provincial and municipal branches of government have extensively supported research on the health of refugee populations in Canada. Under the auspices of Health Canada, Toronto Public Health and the Association of Local Public Health Agencies (2003) acknowledges that the health of migrant's is a reflection of the environment from which they came, their migratory journey, as well as the challenges of permanent resettlement.

Significantly lower rates of migrant's accessed health services because of the barriers they encounter (ALPHA, 2003). Stampino (2007) corroborates this finding, and suggests an intermingling of structural and social factors, indicating that if the systemic challenges were to be eliminated and the social factors mitigated; immigrant and refugee health may be maintained and even improved over time.

There is also a cultural component to the equity of access debate. According to Kemp \& Rasbridge (2004), specific cultural competence refers to the skills and knowledge "applicable to patients and communities from specific cultural backgrounds" (р. 5). In treating refugee populations, additional steps need to be taken (e.g. language interpretation) to accommodate the needs of refugees and to ensure effective service delivery. Often, health care professionals are unable to understand or interpret the cultural signals that refugees present.

For example, in some cultures (including my own), maintaining eye contact with and responding back to an authority figure like a physician (or an elder) is unacceptable. Some refugees may not know how to ask questions or what questions to ask. Furthermore, they may not know how to coordinate all the 
elements required for their appointments. Consequently, the health problem and needs of refugees may be missed. Although the issue of cultural competence can be tackled at the individual level, institutions also need to work towards cultural competence (Kemp \& Rasbridge, 2004; Stampino, 2007).

Because of systemic, socio-cultural, economic, and linguistic barriers to accessing health care, some refugees may choose not to consult medical professionals and, as a result, employ informal practices. In her study of the healing pursuits of Cambodian refugees in the United States, Pickwell's (1999) subjects "complained of the inconveniences of appointment making, dealing with translators, inadvertently receiving bills for procedures covered by [the health care system and] submitting to tests of which they are afraid..." (p. 169).

Refugee health has also been assessed from a feminist gender perspective. The majority of gender analysis of refugee health is female centric because immigrant women generally, and women of colour specifically are typically poorer than the mainstream populations. Therefore, even though gender does not refer exclusively to women, most gender analyses of refugee health have focused on women's experiences (Anderson, 2000b; Agnew, 2002; Douglas, 2004; Forget, Deber, Roos, \& Walls, 2005; Spitzer, 2005). This feminine centered research is in part a corrective to a historically androcentric health research legacy, which marginalizes women.

Although governments have enacted policies to ensure the equitable treatment of men and women in the health care system, illness and disease have a differential impact on men and women. According to Courtenay (2004), "asking for help and caring for one's health are widely considered to be the province of women... [thus] women are the greatest consumers of health-related products and services" (p. 275). Gendered social norms dictate what is appropriate for 
men or women, and foster incorrect perceptions about health behaviour (Courtenay, 2000, 2004; Nghe et al., 2003; Pottie et al., 2005; Macnaughton, 2008). It thus logically follows that refugee men and women conceptualize their health in different ways.

Refugees and other classes of migrants continue to fill the demographic gap in Canada. While only a few studies have examined the experiences of refugee men, even fewer studies have compared refugee men and women's experience of health service access. Refugee health access can be examined through several theoretical frameworks. This paper will however, employ the antioppression and anti-racist frameworks to review the nature of oppression in Canada. While the former questions the social divisions and structural barriers in society, the latter views race as the starting point to analyses of structural barriers and institutional change (Calliste \& Dei, 2001; Mullaly, 2002a; Dominelli, 2002; Yee, 2005). Issue of equity of access for refugee men and women need to be situated in critical theories that advance strategies for the dismantling of entrenched historical inequalities.

\section{The Historical Oppression of Racialized Minority Newcomers: A Theoretical Framework}

While every person in society can profess being oppressed by virtue of the expectations, regulations, boundaries, and barriers advanced by institutions and structures in society, the simple restriction of one's freedom and choice cannot be considered oppression (Mullaly, 2002a). Oppression is a socially constructed power imbalance based on race, gender, class, etc. in a society that 
is group-based, and involves the privileged oppressor reaping social goods, to the detriment of the underprivileged oppressed (Mullaly, 2002a).

According to Mullaly (2007), "oppression protects a kind of citizenship that is superior to that of the oppressed" (p. 194), and results in groups experiencing limited access and/or limited participation in society. Embedded in this process are broadly accepted distortions and interpretations of social reality, which are subliminally and unconsciously learned through socialization (Hardiman \& Jackson, 1997; Mullaly, 2002a; Abu-Laban \& Garber, 2005). An analysis of Canada's history as a settler colony is relevant, and central to a discussion of anti-oppressive and anti-racist social change.

Canadian immigration has been a nation-building tool, which has also played an important role in the exploitation and expropriation of resources from the indigenous population. Since its initial settlement, Canada has been framed as a "white, masculinist, heterosexual, Christian, and capitalist" (Grace, StrongBoag, Anderson \& Eisenberg, 1998, p. 9) settler colony. This framing directed the organization and distribution of power and resources along ethnic, racial, class, and gender lines (Abu-Laban \& Garber, 2005). Additionally, this historical identity facilitated the mass immigration of European migrants who were officially considered more desirable than non-European immigrants (Kelley \& Trebilcock, 1998; Thobani, 2000; Abu-Laban \& Garber, 2005).

The social construction of "the desirable" versus "the undesirable" immigrant enabled the consolidation of political power in shaping public policy (Grace et al., 1998; Abu-Laban \& Garber, 2005). Guided by this Eurocentric ideology Canadian policy makers enacted oppressive legislations, such as the Chinese Immigration Act of 1885 - the Chinese head tax, the Japanese internment camps, and the continuous-journey requirement for South Asians 
(Grace et al., 1998; Kelley \& Trebilcock, 1998; Abu-Laban \& Garber, 2005). The nineteenth century legacy of domination and oppression informs all areas of social life and clarifies the existence of the many inequities that pervade contemporary Canadian society.

Debatably, the historical tendency towards preserving Canada's "whiteness" continues to be in contention, as this identity has both been integrated at the institutional level and internalized at the individual and societal levels (Thobani, 2000; Mullaly, 2002a). Even though changes to Canada's immigration policy enabled a shift in immigrant source countries from traditionally European to non-European nations, immigrants continue to be oppressed by programs and policies that were established to meet "the needs of white people and not the needs of the marginalized groups themselves" (Yee, 2005, p. 93). Immigrants, refugees, and racialized communities are some of the marginalized groups in Canadian society.

Research suggests that non-European refugees and immigrants encounter barriers to full participation in the institutional and societal fabric of Canada (Galabuzi, 2001; Omidvar \& Richmond, 2003; Plouffe, 2003; Lacroix, 2004; Simich, Beiser, Stewart \& Mwakarimba, 2005; Abu-Laban \& Garber, 2005; Yu, Ouellet \& Warmington, 2007). Refugees have consistently comprised about ten percent of Canada's yearly immigration quota. While there are some variations in the ethno-racial composition of resettled refugees in Canada, most are from the developing world. In fleeing for their lives, refugees suffer many losses, but they also struggle to socially and economically integrate into Canadian society.

The notions of settlement, resettlement, integration and upward mobility lie at the core of established migrant narratives (Abu-Laban \& Garber, 2005). The 
achievement of this mobility is facilitated by access to quality assistance from governmental and nongovernmental social service agencies. Textual analysis identifies several measures of integration namely, "labour force participation, income, house ownership, wealth, residential segregation, language skills and use, educational attainment, social networks, cultural consumption patterns, physical and mental health... and various attitudes" (Yu et al., 2007, p. 18).

Though refugees are admitted based on different selection criteria than other immigrant classes, immigrants and refugees are likely to encounter similar challenges because of limited language skills, unrecognized foreign credentials, and difficulty finding adequate employment (Omidvar \& Richmond, 2003; Lacroix, 2004; Yu et al., 2007). Refugees are also more likely to experience a decline in health; more likely to be unemployed; and more likely to be poor (Beiser, 2005b; Yu et al., 2007). The traumatic nature of refugee migration explains why their integration is distinct from that of other more voluntary immigrant groups.

Thus, specialized, culturally sensitive, and easily accessible services are necessary to facilitate the resettlement and integration of refugee and immigrant populations. Nonetheless, the institutional responses to Canada's diverse population occur at a slow pace. The slow institutional reaction to an increasingly diverse Canadian population should be assessed in light of the socio-political discourse surrounding new settlers who have been traditionally linked with declining standard of living compared to the existing population (Dauvergne, 2005)

Like many other countries, Canada has been cautious about admitting immigrants who have historically been perceived of as threats to the health of the general population, and the economic wellbeing of the nation. Studies suggest a link between immigration, welfare reform and access to social services (Arat-Koc, 
1999). Immigrants in general, particularly refugees have been viewed as burdensome "undeserving foreigners" (Ferguson et al., 2005, p. 132).

Although the long standing "sick immigrant paradigm" has been replaced by the "healthy immigrant paradigm", one can argue that such socio-political concerns continue to affect research priorities and the care of newcomers to Canada (Beiser, 2005b). An example of this implicit concern is evident in the Interim Federal Health Program, which provides government sponsored refugees (GARS) with limited access to health services during their first three months in Canada (ALPHA, 2003).

This policy excludes asylum seekers who claim refugee status upon landing in Canada, and who have not been conferred the status of protected persons. Conferring the status of protected person on mainly government and privately sponsored refugees' renders asylum seekers subject to a system that is fundamentally oppressive. Such policies reveal that systemic discrimination continues to be a significant barrier to newcomer's experiences with Canadian institutions. Refugee communities neither experience full civic participation, nor full access to social services.

Premised on the existence of divisions and structural barriers in society, the anti-oppression framework provides a holistic assessment of peoples' lived reality (Dominelli, 2002; Mullaly, 2002a). It is integral to understanding marginalization, and deconstructing all facets of oppression based on race, class, age, disability, or sex. Rooted in principles such as access, inclusiveness, respect, accountability, advocacy, and equity, anti-oppressive practice is concerned with improving the quality of life and well being of oppressed groups (Hardiman \& Jackson, 1997; Mullaly, 2002a). 
Considering Canada's colonial past, it is clear that notions of racial superiority or inferiority, and desirability or undesirability have been central to public discourse and immigration policy. Although it can be argued that historically situated conceptions of racialized groups have receded from mainstream social discourse, institutions and structures in society continue to be instrumental in defining the identities of among others, ethnic, racial, and class minorities (Calliste \& Dei, 2001). In reality, race, ethnicity, class, and other categories of difference influence the distribution of access to power and opportunities.

For these reasons anti-racist theory views race as the entry point to analyses of structural barriers and institutional change (Calliste \& Dei, 2001; Mullaly, 2002a; Dominelli, 2002). By emphasizing the power differentials between dominant and subordinate groups in society, both the anti-oppression framework and anti-racist theory problematize the status quo and the questionable ideas underlying established definitions of achievement, merit and success (Calliste \& Dei, 2001). While not all immigrants and refugees experience marginalization, social, systemic and institutional racism affects the kinds of services, employment opportunities, and training open to racialized groups, and determines the kinds of research initiatives endeavoured by policy makers.

In order to affect change, the state has to play a crucial role in creating the necessary institutional framework to eliminate oppression and racism, as well as providing fiscal assistance and policies that support anti-oppressive and anti-racist efforts (George, 2000). The next section presents an analysis of how neoliberal ideology has challenged the 


\section{Canadian health care system, and subsequently further alienated already marginalized groups whose health is likely fragile.}

\section{Canadian Health Care: A Question of Universality}

Health care can be described as one of the main aspects of a nation's social policy. Consumer welfare in a health care system is associated with issues of safety, health education and information, socio-political efficacy and redress, accessibility, availability, quality, as well as cost (McGregor, 2001). It is thus plausible that if a consumer is poor, has limited health education, and is a casualty of institutionalized exclusion; their health and welfare may likely be in question. In a universal health care system like Canada's, which is supposed to be accessible to all, barriers to health care are prevalent.

Premised on the central concepts of public administration, universality and accessibility, Canada's universal health care is one of the country's proudest accomplishments and the envy of many neighbouring and distant nations alike. This publicly funded health care system was established to ensure that all permanent residents and citizens are able to access health services regardless of class or any other categories of difference (Chen, Hou, Sanmartin, Houle, Tremblay \& Berthelot, 2002; Browne, 2004; Quan, Fong, De Coster, Wang, Musto, Noseworthy \& Ghali, 2006).

However, economic globalization and its related restructuring processes have led to the transnationalization of health, and manifested in cuts to national health care spending and the gradual shift towards privatization (Anderson, 2000b; McGregor, 2001). Even though this system has worked relatively well for many years, in the last decades, it has been plagued by shortages, service 
delays, rural versus urban disparities in access, inadequate access to and coverage for prescription drugs, as well as dental and eye care services (Browne, 2004; Ontario Council of Agencies Serving Immigrants-OCASI, 2005).

In the name of efficiency and sustainability, Canadian health policy emphasizes fiscal restraint and personal responsibility for the management of health and disease (Grace et al., 1998; Anderson \& Kirkham, 1998a; McGregor, 2001; Browne, 2004). The trend towards deregulation and for-profit health care has created gaps in care and a decline in consumer satisfaction. For instance, the number of Canadians with unmet health needs increased from $23 \%$ between 1998-99 to $30 \%$ between $2000-01$ because of long waiting periods for medical appointments and treatment (Chen et al., 2002). Consequently, Chen et al. (2002) found that, "only $62 \%$ [of Canadians feel] that [the health care system can] adequately meet the needs of all residents in their province" (p. 18).

Perhaps, the Canadian public's low satisfaction with the health care system is indicative of the public's fear of a weakening health care system that may not be sustainable in the long term and in the face of increased immigration. Furthermore, the Canadian Supreme Court's decision upholding the right of citizens to seek private health care in a way acknowledges the important role access to health care plays in ensuring health and wellbeing. However, this solution departs from the main ethos of equity underlying Canada's publicly funded health system (OCASI, 2005).

What is also problematic is that this decision does very little to mitigate the challenges marginalized groups face, and instead, aggravates existing inequalities of access in the health care system. Immigrants continue to be a crucial feature of Canada's economic policy. However immigrants, especially refugees have been historically viewed and constructed in multiple ways, 
including as an unhealthy burdensome drain on the Canadian welfare (health care) system (Cannon, 1995; Grace et al., 1998; Beiser, 2005b).

Currently, while immigrants account for 18.4 percent of Canada's population, visible minorities comprise 13.4 percent (National Union of Public and General Employees, 2003). By all accounts, Canadian society is now one of the most diverse, multicultural and cosmopolitan in the world. The ethno-racial, linguistic and cultural heterogeneity that comes with Canada's increased admission of Third World migrants holds implications for social institutions and social relations. Though policies (e.g. Canada Health Act, Charter of Rights and Freedoms, Human Rights Code, Employment Equity Act etc.) have been developed to guide the fair treatment of non-white, racialized immigrants, remnants of Canada's oppressive colonial past continue to pervade the social institutions and processes (Anderson \& Kirkham, 1998a).

Although one can argue for the universality and inevitability of social isolation and exclusion associated with migration to a foreign country, newcomers from non-European backgrounds experience greater social exclusion because of discrimination and the inevitable loss of social networks and support that come with immigration. This lack of social support affects the health status of migrants and plays a crucial role in determining the utilization of health services (ALPHA, 2003; Simich et al., 2005).

What is more, immigrants and refugees face systemic barriers, as a result of limited language skills; a lack of awareness and understanding of the health care system and services; lack of culturally appropriate and culturally competent services, decreased funding for community health; and inadequate information from the government and agencies (Stewart, 2003; ALPHA, 2003; Kemp \& 
Rasbridge, 2004; OCASI, 2005; Simich et al., 2005). Because immigrants continue to fill Canada's demographic gap, issues of immigrant settlement and refugee resettlement affects Canada's social policy, particularly health care policy.

By linking the health reform debate with issues of migration and settlement, such analysis enables a consideration of how the restructuring process affects resident populations, especially newcomers who may not feel that they equally share the rights and privileges of citizenship that more established Canadian citizens are allowed (Arat-Koc, 1999). Access to Medicare is a multilayered process involving not only the consumer seeking care, but also the health care system in place, and other factors that may aid or hinder this activity (Chen et al., 2002; Ricketts \& Goldsmith, 2005).

The barriers immigrants and refugees encounter when initially accessing health services shape their perception of the health care system, and may create a resistance toward future utilization/consumption of health services (Ricketts \& Goldsmith, 2005). In most provinces throughout Canada, new immigrants are subject to a three-month waiting period for health coverage. During this period, the only health care available is to be privately funded. The stress, economic marginalization, lack of social networks and support, poor housing, and discrimination that refugees and immigrants face during resettlement and settlement respectively, plays an important role in determining whether or not they choose to access care and/or utilize health services (Chen et al., 2002; Simich et al., 2005). 
Whether forced or voluntary, refugees and other classes of immigrants share a similar migrant narrative - that is, to achieve a relative degree of economic mobility, and socio-political stability (Abu-Laban \& Garber, 2005). Galabuzi (2001) notes that in 2001, 30\% of immigrants compared to $21 \%$ of the Canadian-born population were found to be living under the poverty line - that is less than a gross income of $\$ 35,455$ for a family of four. This statistic mainly reflects the experience of economic class immigrants who are granted admission into Canada, based on a point system that is guided by human capital theory, which emphasizes education and skill (Gabriel, 2006). While refugees, by virtue of their humanitarian migration are selected based on their ability to quickly adapt and integrate into Canadian society.

This distinction is essential to understanding why refugees are more vulnerable to the effects of poverty and greater health problems than other classes of immigrants. During the initial three months in Canada, government sponsored refugees are granted limited access to emergency health services. Despite the 'Don't Ask' policy enacted by the City of Toronto, which prohibits inquiries into a newcomer's immigration status, asylum seekers and undocumented persons may fear deportation when accessing social services, and may resort to private health care that they may not be able to afford (Ontario Coalition Against Poverty-OCAP, 2004).

One's income determines where they live, what they eat, and in some circumstances, how one is treated, and whether one seeks health care. As such, a decline in social and economic status results in poverty and/or income inequality, and has also been linked with poor physical and mental health, as well as mortality. A longitudinal survey of Canada's immigrants found that $19 \%$ felt the 
costs of prescription drugs and dental services were too high (OCASI, 2005). Compared to Canada's endemic population, immigrants and refugees access and utilize health services at significantly lower rates (Barnes, 2001a; ALPHA, 2003, OCASI, 2005).

Although advocates of health care reform propose the enactment of user fees, additional billing, co-payments, deductibles, and a medical banking system, critics argue that such amendments would make accessing health care dependent on one's ability to pay, instead of one's need (Browne, 2004; Forget et al., 2005). From this analysis, one can argue that health care reform compounds the existing vulnerabilities, as well as the health status and outcomes of refugee men and women. Clearly, the expressed ideal of equity in Canadian health care differs from the reality.

McGregor (2001) notes, "the health status of a nation can be a reflection of the health policy in place" (p. 82). Thus, while selective immigration policies ensure the entry of mainly healthy immigrants and relatively healthier refugees into Canada, the decline in health experienced by refugees and immigrants once in Canada, including barriers to access, and underutilization of health services can be better understood by examining and questioning Canada's health care policy and system (Anderson, 2000b; McGregor, 2001; Chen et al., 2002; Newbold, 2005b; Beiser, 2005b). Health seeking is also a gendered process that holds implications for health and wellbeing of refugees. In the following section, I will provide a gender analysis of the differences in the health seeking behaviours of refugee men and women. 


\section{Gender Differences in Health-Seeking Behaviour}

Health-seeking behaviour can be defined as the independent and/or collective actions and process of maintaining and/or returning to health (Scrimshaw \& Hurtado, 1984). Several models for understanding health-seeking behaviour have been advanced in the fields of social psychology, medical sociology, and medical anthropology. These models explore health beliefs, planned behaviour, reasoned action, health service utilization and other socialbehavioural and decision-making dynamics (Hausmann-Muela, Rebera \& Nyamongo, 2003). Within the realm of public health research, these models enable an examination of the multiple factors that explain and may aid in predicting health service utilization.

My discussion will focus on the health belief model and what has been called the "four A's" model (Hausmann-Muela et al., 2003). The latter examines the availability, accessibility, acceptability and affordability of health service in identifying barriers to health care. The health beliefs' model considers the following: perceived effects and consequences of illness; the motivation and concern about one's health; the perceived advantages and disadvantages of preventative health practices; the internal and external signals that influence action; and the socio-demographic (e.g. class, gender etc.) and psychological factors (e.g. peer group pressure) that determine health seeking behaviour (Hausmann-Muela et al., 2003).

Even though Canada's universal health care system is relatively affordable, acceptable, available, and arguably accessible to all legal residents, one's health beliefs acquired through socio-cultural and gender socialization may help predict health service utilization. Gender and/or the respective roles 
attached to being male or female play a significant part in determining health. Men and women share different social norms and beliefs about health.

While women are ascribed the role of expressive caregiver, men are trained to be the instrumental breadwinner. Not surprisingly, the gender division of labour greatly determines the quality of life and life expectancy of men and women. On average, women (81 years) live five years longer than men (76 years). Yet because women perform a disproportionate amount of unpaid domestic work, including child rearing and other familial social relations, they are less likely to work for wages, and more likely to live their latter years in poverty and in a state of poor health because of chronic conditions (Grace et al., 1998; Anderson, 2000b; Statistics Canada, 2007; Spitzer, 2005).

Language barriers determine the kinds of employment one performs and socio-economic status, which in turn determine health. While immigrant women are least likely to speak any of the official languages upon arrival in Canada, their male counterparts typically speak either English or French, and have more opportunities to learn because of their traditional role as wage earners in the labour market. In spite of this clear advantage newcomer men have over their female cohort, immigrant women tend to benefit more from English as a second language (ESL) programs (Beiser \& Hou, 2000a).

Nevertheless, according to Statistics Canada (2007b), the unemployment rate for newcomer "women who had been in Canada for five years or less was 13.0\%" compared to the $10.3 \%$ rate for newcomer men. Racialized immigrant and refugee women whose voices have typically been absent from the health care policy reform discourse suffer poor health, not because of lifestyle choices, but because of racism and economic inequalities resulting in poverty (OCASI, 2005). 
In comparison, refugee and immigrant men have not been exempt from the adverse outcomes of health care reform. While working in mainly manufacturing sector jobs (Statistics Canada, 2007), newcomer men may not be aware of their rights as labourers, and may be exposed to hazardous materials and dangerous working conditions. Bearing in mind the masculine social norms conflating self-sufficiency and independence with strength and power, screening and diagnosis for illness may occur during the late stages of ill health. This may result in their inability to work and afford treatment medications, and it is plausible that subsequent feelings of despair affect their mental wellbeing.

Spitzer (2005) indicates that men die earlier because of risk-taking behaviour that may result in the increased exposure to injuries and accidents. Furthermore, research suggests that these disparities in health are the result of an intermingling of factors ranging from "the demands of multiple gender roles, environmental exposures, the threat and consequences of gender violence, workplace hazards, economic disparities" (Spitzer, 2005, p. 80) poverty, aging, racism and marginalization, health status, and health-seeking behaviour (Matthews, Manor \& Power, 1999; Doyal, 2000; Amaratunga, 2000).

These gender roles and relations produce distinct experiences, reactions to pressures, and health-seeking behaviours, which lead to diverse health outcomes. Unlike women who are socialized to ask for help and care for their health, men are conditioned to be self-sufficient and independent. Thus, if women care for themselves, their considered 'hot babes' or mothers, but men care for themselves they are labelled 'sissies' (Courtenay, 2004). These questionable perceptions result in men being more reactive in seeking help or health care, while women tend to be proactive in accessing health services. According to Statistics Canada (2001a), women of childbearing age (between 20- 
49 years) are more likely to have contacted a general practitioner, consulted a specialist or visited a hospital than their male counterparts.

Although there are slight cultural variations in gender roles, relations and expectations worldwide, one can safely say that this gender division of labour is characteristic of both developing and industrialized nations. But gender roles are not static, rather, these roles and relations continuously change over one's lifetime, and may influence one's ability to access social resources such as health care (Spitzer, 2005). For instance, because men traditionally occupy a position of power in society that may ensure a degree of preferential access to health care, this privileged status may change.

Upon migrating to a culturally, linguistically and ethnically distinct society like Canada, immigrant and refugee men from the developing world may experience a decline in social status and social capital. Furthermore, they cannot benefit (i.e. fully) from the de facto institutionalized gender bias, which favours middle class white men in the host society. It is therefore important to assess the health-seeking behaviour of refugee men and women in Canada, who in recent years have been resettled from Third World nations with distinct linguistic, religious, and cultural prescriptions and practices.

In fleeing for their lives, refugees leave their homes, livelihoods, and material possessions. As the frontline targets, most men are killed, while women and children are subjected to violence, and endure famine, as well as the loss of the breadwinner and kin who offered social support. They are forced to live in crowded and unsanitary refugee camps for protracted periods of time (Taft \& Baird, 2004). Yet, despite some differences in the experiences of refugee men and women before migration, upon migration, both find themselves in a completely foreign land with different values, culture and language. 
Even though women and children comprise the majority of the global refugee population, Canada accepts slightly more male than female refugees. Considering the patriarchal ideology that shapes the social and institutional relations in developed and developing countries, it is not surprising that immigrant and refugee men tend to have more human capital (e.g. education, skills etc.), and may thus be more attractive candidates for resettlement. However, both struggle and face major role changes, which impact their health status, health-seeking and health outcomes.

Through their exodus, the loss of social status and material possessions, refugees arrive in Canada with the hope of rebuilding better lives for themselves. Yet in addition to a priori experience of trauma and displacement, refugee men and women face discrimination, racism, unemployment, underemployment, and general economic hardships in the host country (Agnew, 2002; Nghe et al., 2003; Douglas, 2004; Lacroix, 2004; Pottie et al., 2005; Macnaughton, 2008).

A review of the literature on the respective experiences of refugee men and women suggests that, most refugee women and poorer refugee men encounter common challenges and barriers during resettlement in the host country (Courtenay, 2000; Agnew, 2002; Lcroix, 2004; Pottie et al., 2005; Spitzer, 2005; Beiser, 2005b). Refugee men's (and women's) experience of pre-migration trauma and continued marginalization during migration limits their agency because of lack of opportunities. The pre and post migration experience coupled with isolating gender norms that link strength with self-reliance, all influence the help seeking and health-seeking behaviour of resettled refugee men (Nghe et al., 2003; Pottie et al., 2005).

Research suggests that, as a broad category, women seek health services more frequently than men (Chen et al, 2002; Statistics Canada, 2001). 
However, the overrepresentation of immigrant and refugee women in low-wage and temporary manufacturing jobs deleteriously affects their health. In a society where the interests, culture, values, "... physiological and psychological needs of middle class white women inform the kinds of services available to all women," women with different identities may feel excluded (Agnew, 2002, p.9).

Feelings of exclusion and alienation may discourage non-white immigrant women from utilizing health services. It is thus important to account for the diverse experiences, exposures and pressures that racialized immigrant women encounter. The refugee experience coupled with the stressors related to acculturation, integration and discrimination in Canada renders refugee men and women vulnerable to distress, which affects their health and utilization of health services. Overall, by examining treatment-seeking behaviour, we can understand how gender factors into the motivations and rationale behind accessing or not accessing health services. In the following section, I will provide a theoretical discussion of access, and the barriers that hinder access, as well as the opportunities that may improve the utilization of health services.

\section{Issues in Access Reviewed}

Ricketts and Goldsmith (2005) have suggested that "access [is] more a political than an operational idea" (p. 274). The process of access is initiated when one seeks screening because of the development and awareness of visible as well as unnoticed illness, and/or injury (Ricketts \& Goldsmith, 2005). Thus, positive encounters during the screening stage may serve to bolster confidence for future use, whereas barriers have the counter effect. Although the attitude of the patient toward the service provider and the care system is significant, by 
providing a person with client-centered, linguistically specific, culturally sensitive, and well-funded health services and providers, trust and use of preventative services are encouraged and, more importantly, the person is most likely to use available services.

In viewing access as use, it logically follows that service utilization is the proof of access, and not the mere availability of services and facilities. Care seeking therefore, does not only involve the individual, but rather a broad range of actors and middlemen, including institutions and practitioners. While these intermediaries have officially been ascribed the role and purpose of facilitating the health seeking process, their manifest function in relation to immigrant and refugee populations may be the opposite and ultimately impede health service utilization.

In keeping with the cost cutting agenda and strategy of the government, one may argue that this negative outcome is the true, yet latent intent of the health care system to "fiscally gate-keep and control utilization" (Ricketts \& Goldsmith, 2005, p. 278). In essence, the gradual privatization of Canada's health care system is arguably intended to further push the perceived fiscal liabilities (e.g. refugees, elderly immigrants, women, and other racialized groups) into the periphery of Canadian society.

Newly arrived visible minority refugees and immigrants to Canada are more likely to experience inequalities, which affects their health (Simich et al., 2005). Refugees face many difficulties in accessing and utilizing health services in Canada. These challenges are systemic, socio-economic, and cultural/linguistic. At the institutional level, individual and systemic prejudices work together to further marginalize immigrants and refugees. Some systemic impediments include a lack of awareness and understanding of available 
services, lack of cultural competent services and cultural insensitivity on the part of health service providers, and the spatial distribution of support services.

With more cuts being made to health care, community health programs, as well as immigrant settlement services, service gaps have been created, and in turn, the access and use of social services has been affected (Stewart, 2003, Simich et al., 2005). Socio-economically, refugees arrive in Canada with limited to no monetary or material possessions. This state of fiscal deprivation is compounded, as they face discrimination in the labour force and are unable to find stable and well-paying employment.

While government assisted refugees have access to emergency medical services for the first three months upon arrival in Canada, the cost of prescription medical drugs is privately borne. Conversely, asylum seekers and other irregular status immigrants may simply not access health services if they do not have the funds. On the other hand, issues of language, modesty, trust, as well as beliefs and perceptions about health encapsulate the barriers related to culture. Many government-sponsored refugees are selected from refugee camps with abysmal conditions, including poor education and social infrastructure. Consequently, many of the refugees may be illiterate.

Depending on the level of education and the languages spoken in the home country prior to fleeing, some refugees may speak French and/or English, while most speak neither official language, and thus face barriers in communication once in Canada. Experiences of state sanctioned oppression and traumatic foreign occupation may result in a general distrust of government and Western medical systems. Furthermore, culturally specific masculine and feminine norms and expectations have been found to restrict one's choice of health care provider to the corresponding gender of the refugee consumer. 
For instance, Stewart (2003) notes that Somali women prefer receiving treatment from female physicians generally, but especially for sensitive examinations and discussions of a sexual nature. For some refugees, the perceived bad luck that is associated with admitting illness and seeking treatment may determine health service utilization (Williams \& Hampton, 2005). Newbold (2005b) further suggests that perceptions of health and wellbeing vary from one immigrant group to another, and cites Indo-Canadian women's view of depression as a personal, rather than a medical matter.

These barriers contribute to limiting the access of refugees and other racialized immigrants, and add to the individual and systemic impediments that these communities already experience about health care itself and the health care system. Research suggests that because of these factors, refugees and immigrants utilize health services less than the general population, (Wood et al., 1998; Ross et al., 2000; Barnes, 2001a; ALPHA, 2003; OCASI, 2005).

The necessary elements needed to improve health service utilization for refugees and immigrants can be adopted from the social support and social inclusion frameworks. These paradigms examine both the social and systemic dimensions of integration. Simich et al. (2005) note that, during major transitions, such as immigration, social support in the forms of family, peers, and friends who play the role of emotional anchors, as well as professionals who supportively communicate practical information are as crucial as the essential commodities (e.g. food, shelter etc.) of life.

Omidvar and Richmond (2003) also add that, in order to achieve equity and social inclusion for refugees and immigrants, there needs to be a deconstruction of exclusionary political, economic, and socio-cultural barriers, which restrict the acceptance and recognition of newcomers. By integrating 
research conducted from an anti-oppressive framework with these frameworks, which cut across all sectors and institutions, a holistic analysis of refugee health access is achieved, thus clarifying the possible remedies to improve the utilization of health services.

One such remedy relates to increased funding for the refugee assistance program and other immigrant social and settlement services, especially the ethno-specific community agencies that provide culturally sensitive specialized health services for newcomers (Sadiq, 2005). Another recommendation is to improve access to multilingual information and services for refugees, which will facilitate the bridging of the language divide and may also encourage the use of pertinent social services, like heath care (Stampino, 2007).

Poverty is a key determinant of health. Immigration policy that emphasize human capital, results in high levels of unemployment among refugee and immigrant populations who are relegated to underemployment and poverty, as they cannot find well-paying jobs, or jobs in their professional fields. Even though refugees are not admitted based on their skill, their health, resettlement and integration is also hampered by the challenges they encounter in the labour market. The difficulties these communities face during resettlement suggest shortcomings in social and immigrant settlement policies (Beiser, 2005b).

\section{Towards a Postcolonial Feminist Scholarship of Refugee Health}

In this era of heightened capitalism, the conditions arising from the movement of colonial societies into postcolonial societies have served as a catalyst for militarism in many developing nations, and the subsequent displacement of millions of people worldwide. What is more, the structural forces 
and processes of economic globalization have affected most women, as well as poor working class men in ways that are not only deleterious to their health and wellbeing, but also impacts the health care they receive and their utilization of health services (Anderson, 2000b).

In both developing and developed nations, the discourse of structural adjustment or fiscal conservatism has translated into a steady decline in the state's responsibility for social welfare and security. The status granted to newcomers in immigrant receiving countries like Canada is a reflection of the position they occupy in the global order of labour and capital (Grace et al., 1998). Refugee health thus needs to be understood and interpreted within a global and national economic order of neoliberal cost containment. To address the barriers that refugees experience in access to health services, it is necessary to critically assess the climate in which Canada's health care system was constructed.

Canada's health care system should be analyzed within a gendered, raced, and classed socio-political context (Anderson \& Kirkham, 1998a; Anderson, 2000b). While 'universal' health care is one of Canada's greatest accomplishments, there are inherent contradictions in this system that are inextricably linked to Canada's primordial construction as a white settler colony. The notions of self-sufficiency, egalitarianism, and independence, which formed the basis of the Canadian nation, also shaped the health care system (Anderson \& Kirkham, 1998a). This ideology and its related expectations presuppose the equality of all citizens. In other words, if there is equality of access to health services, everyone should achieve the best health outcomes.

This laissez-faire ideology makes it easier for governments and health policy makers to avoid reviewing the social and structural barriers that shape people's access to health care and the use of health services. Furthermore, such 
ideologies implicitly justify inequalities and establish "a rhetoric of equality" that does not translate into substantive change (Anderson \& Kirkham, 1998a, p. 243). While many social theorists may share a common concern about social inequalities, some have dismissed the colonial experience of Third World nations as misleading and incongruent with Canada's socio-political patterns as a settler colony (Frideres, 1993).

This however begs the question: are Canada's Aboriginals not the victims of an oppressive colonial power structure that has held disastrous implications for their health and wellbeing? Just based on media reports, and simple social observation in Canada's urban cities, one can answer this question in the affirmative. The colonization and subordination of Aboriginal people is evidence of a nation-building agenda that adversely impacted their health and perpetuated negative stereotypes (Anderson \& Kirkham, 1998a). Canada's nation-building strategy has also dictated the treatment of Eastern Europeans, Chinese, and Indian immigrant labourers who were required for agricultural and infrastructural development projects (Kelley \& Trebilcock, 1998).

Canadian immigration policy has been the instrument of oppression and marginalization, as Chinese and Indian labourers were discouraged from seeking permanent residency and sponsoring their wives and family. The practice of 'othering' also manifested in the character examinations and medical health screening new settlers were subjected to (Anderson \& Kirkham, 1998a; Kelley \& Trebilcock, 1998). Even with the passing of civil and human rights legislation (e.g. Charter of Rights and Freedoms 1982, the Multiculturalism Act 1988) to guide the equalization of the proverbial playing field for all, social inequality persists in Canadian society (Anderson \& Kirkham, 1998a). 
Despite the concern about social inequality commonly shared by critical social scientists, self-reflexivity requires one to consider what Anderson (2000b) calls the "positionality" of the researcher and the theory being constructed ( $p$. 225). This simply means that even the most well-intentioned researcher may not be aware of his/her own social location and claim neutrality, when in fact, values are being expressed. The researcher's social location shapes his/her interests, experiences, motivations, and broader worldview, and may inadvertently contribute to the racialization and 'othering' processes that are inscribed upon certain groups (Grace et al., 1998, Anderson, 2000b).

Postcolonialism addresses the value laden nature of Western academic discourse by drawing attention to the "process by which concepts such as ethnicity, race, and culture have been constructed and used to create binaries by locating non-European peoples as the essentialized, inferior, subordinate Other" (Khan, McDonald, Baumbusch, Kirkham, Tan \& Anderson, 2007, p. 230). Furthermore, by acknowledging the dynamic effect colonization had on the colonized, postcolonial discourse confronts the view that subaltern cultures are fixed (Khan et al., 2007).

While sharing an aversion for the civilizing mission of colonialism and its legacy, postcolonialism and anti-colonialism differ in that the former is not limited to resistance, as it characterizes "societies whose subjectivity has been constituted by the subordinating power of European colonialism" (Childs \& Williams, 1997, p. 232). The fact that millions of people currently live in the world shaped by decolonization justifies the use of postcolonial theory, which has generally been preoccupied with the recovery and re-evaluation of indigenous histories (Childs \& Williams, 1997). 
Postcolonial writings thus attempt to rectify the historically constructed epistemological deficit in Western scholarship by developing a framework through which subaltern voices can be heard, thereby enabling a critical examination of multiple social locations in research and policy making (Anderson, 2000b). Postcolonial theory makes space for the consideration of research that takes into account interrelated processes, such as racialization, colonialism, neocolonialism, globalization, marginalization and class relations, and their impact on health (Anderson, 2000b).

On its own, postcolonial theory lacks a gender orientation. However, the coupling of Black feminism, which argues for the intersectionality of sexism, racism and class oppression, with postcolonial scholarship provides a framework for all women, and poor men whose voices have largely been silenced (Khan et al., 2007). As a methodological framework, postcolonial feminist theory comprises several elements. First, it serves as an analytical framework that enables the concurrent consideration of culture, history, gender, race and class. Second, it allows for deductive reasoning connecting "micro and macro levels of analysis" (Khan et al., 2007, p. 231).

Third, postcolonial feminism encourages agency by emphasizing a bottom-up assessment of marginalization through the eyes of the oppressed. Fourth, the experience of marginalized groups is used as a sort of standpoint epistemology from which transformative policies are constructed and implemented (Khan et al., 2007). Postcolonial feminist theory enables the development of what Anderson (2000b) has called "transformative knowledge" (p. 225). In effect, knowledge that encourages transformative social change using a critical orientation that elucidates processes of domination and 
subordination, and unequal power relations based on gender, race, and class assumptions (Anderson, 2000b; Khan et al., 2007).

Poverty and institutional exclusion affect who accesses and utilizes health services. The mainly racialized refugee population is only one of the socially, economically, and institutionally marginalized groups in Canada. Yet refugee health discourse has largely centered on cultural meanings and dimensions of health and help seeking. Overall, if we are to understand and conduct research that can efficiently be translated into policy, there needs to be a shift from the assimilationist stance in policy to a postcolonial feminist standpoint (Anderson, 2000b; Khan et al., 2007).

\section{Conclusion}

The origins of refugee migration are connected to many pressing world issues including, economic inequality, conflict resolution, health, and human rights, as well as population management. Increased international migration to industrialized countries like Canada holds social and political implications, as the very nature and composition of refugee migration calls for a multi-sectoral reevaluation of social and resettlement programs and institutional practices. The health status and health service utilization of immigrant populations should be viewed as measures and indicators of integration in host countries like Canada. Refugees and other classes of immigrants, regardless of their country of origin tend to be healthier than Canada's domestic populations. However, over time their health declines to parallel that of the existing population. By including health in the settlement calculus, this decline can be interpreted as indicating the need for improved social and settlement policies. 
Although the admission criteria differs from one immigrant category to another, both immigrants and refugees are likely to face language barriers, discrimination in the labour market and society at large, as well as poverty, which in turn affects their health. The refugee experience of trauma and oppression pre-migration, coupled with the stresses of settlement, and undocumented status in the case of asylum seekers, as well as negative experiences associated with cultural insensitivity in accessing health care, manifest in the limited use of health services.

As a country with a universal health care system, it is surprising to find that health care is not universally accessible. The neoliberal ideology, which inspires social service reform, has led to cutbacks to public health programs and the de-listing of services resulting in the privatization and individuation of health care. While health care reform processes have impacted poor, racialized immigrant and refugee women most, their male counterparts have also been adversely affected.

Gender norms and expectations also shape both the health and health service utilization of refugee men and women. As the breadwinners, refugee men tend to speak one of Canada's official languages (French or English), as they are more likely to interact with mainstream populations in the labour market both pre and post migration. Yet despite the linguistic advantage, immigrant and refugee men are overrepresented in Canada's manufacturing sector, where their health is likely to be affected because of exposure to distinct performance pressures and harmful materials.

For these men, the subsequent utilization of health services is tempered by an intermingling of male gender norms, cultural scripts, and other systemic factors that guide their decision to seek health care. In contrast, immigrant and 
refugee women, by virtue of their role as caretakers of children and the home do not typically speak any of the official languages prior to migration or once in the host country. Despite their disposition towards seeking health care, and their acute responsiveness to opportunities to learn English, refugee and immigrant women are more prone to unemployment and poverty, which affects their shortterm and long-term health.

What is more, lack of culturally sensitive services, and limited understanding and familiarity with the health care system determines their health service utilization. The programs and services have been effectively set up and utilized primarily by mainstream groups and, as a consequence, their outcomes are different from that of newcomer populations. Therefore, the Ontario Council of Agencies Serving Immigrants (2005, p. 4) suggests that "when examining the impact of health care reforms it becomes imperative to carry out equity analysis since the reforms may adversely affect the health of vulnerable subgroups in the population" including refugees.

The anti-oppressive framework serves to enhance one's understanding of how historically entrenched marginalization has evolved and manifests in contemporary Canadian society. More specifically, in doing equity research, the postcolonial feminist paradigm enables the exposing and interruption of "systemic oppressive forces" (Anderson, 2000b, p. 227) that organize social life. One can argue that the process of othering experienced by refugees and racialized immigrant groups in Canada represents a continuation and reproduction of colonial relations of exclusion and domination. Perhaps the underutilization of health services by refugee communities is symptomatic of resistance to re-colonization. 
The health status of immigrants, especially the health of refugees is contingent upon their entry class (e.g. independent versus refugee class), country of origin, cultural retention and acculturation, previous health practices and exposure to the western medical system (Beiser, 2005b). Yet, the term 'immigrant' homogenizes and obfuscates the national, historical, political, and socio-cultural distinctiveness of the people that fall within its parameters. In using this term as a key word when searching library, database and the internet for information on refugee health, one will find generated a wide array of peer reviewed scholarly studies that upon review were clearly rooted in data, which accounted for general immigrant characteristics and the challenges of settlement. Therefore, research models that incorporate the fore mentioned factors, as well as the effects of preventative practices are necessary. More comparative research that considers the distinct experiences of immigrants and refugees in relation to members of the hosting country is required. In conducting searches for secondary research on refugee health, it became clear that there is a dearth of literature assessing the role of gender in shaping refugee health service utilization upon resettlement.

There are very few studies comparing refugee men and women's experiences when accessing health services. Using the tools of primary research, such as interviews and focus groups, and by focusing on a particular ethno-cultural group, future studies on refugee health should examine how gender norms factor into refugees' decision to access health services. Such research has the potential to uncover other issues not discussed in this paper, and may yield more interesting and novel information about the experience of refugee men and women when accessing health services. 
Additionally, studies that uncover the heterogeneity within immigrant and refugee populations' are necessary for a better understanding of the differences and similarities in comparison to more established members of Canadian society. Research that addresses the intra-group and intra-cultural dynamics of refugees' versus immigrants necessitates an understanding of the particular mechanisms and/or combination of factors that translates into risks in health. Inasmuch as policy holds implications for health, the effects of policy on the health of refugees should also be considered in policy making. Critical theories of equity, such as postcolonial feminism allow for the inclusion of historically marginalized voices, so as to facilitate an understanding of their condition and the remedies for change. 


\section{References}

Abu-Laban, Y. \& Garber, A. (2005). Geography of Immigration. Urban Affairs Review, 40(4), pp. 520-561.

Adams, K. M., Gardiner, L. D., \& Assefi, N. (2004). Healthcare challenges from the developing world: post immigration refugee medicine. BMJ, 328(26 June), pp. 1548-1552.

Agnew, V. (2002). Part II: A Literature Review on Health. Gender, Migration and Citizenship Resource Project. Retrieved May 12, 2008 from the World Wide Web: http://www.swc-cfc.gc.ca/pubs/pubspr/gender_migration/index_e.html

Ali, J. S., McDermott, S., \& Gravel, R. G. (2004). Recent Research on Immigrant Health from Statistics Canada's Population Survey. Canadian Journal of Public Health, 95(3), pp. 19-I13.

Allotey, P. A. \& Reidpath, D. D. (2003). Refugee intake: reflections of inequality. Australian and New Zealand Journal of Public Health, 27(1), pp. 12-16.

Amnesty International Canada. (2008). Refugees In Canada. Retrieved June 12, 2008, from the World Wide Web:

http://www.amnesty.ca/Refugee/myths.php

Anderson, J. M. \& Kirkham, S. R. (1998a). Constructing Nation: The Gendering and Racialization of the Canadian Health Care System. In V. Strong-Boag, S. Grace, A. Eisenberg \& J. Anderson (Eds.) Painting the Maple: Essays on Race, Gender, and the Construction of Canada (pp. 242-261). Vancouver: UBC Press.

Anderson, J. M. (2000b). Gender, 'race', poverty, health and discourses of health reform in the context of globalization: a postcolonial feminist perspective in policy research. Nursing Inquiry, 7(4), pp. 220-229.

Arat-Koc, S. (1999). Neo-liberalism, State Restructuring and Immigration: Changes in Canadian Policies in the 1990s. Journal of Canadian Studies, 34(2), pp. 31-52.

Association of Local Public Health Agencies- ALPHA. (2003). Migration Health Conference:Towards a Migration Health Framework for the $21^{\text {st }}$ Century: Final Report. Retrieved May 15, 2008 from the World Wide Web: http://www.alphaweb.org

Barnes, D. M. (2001a). Mental Health Screening in a Refugee Population: A Program Report. Journal of Immigrant Health, 3(3), pp. 141-149.

Barnes, D. M., Harrison, C., \& Heneghan, R. (2004b). Health Risk and Promotion Behaviours in Refugee Populations. Journal of Health Care for the Poor and Underserved, 15(3), pp. 347-356. 
Beiser, M., Hou, F. (2000a). Gender Differences in Language Acquisition and Employment Consequences among Southeast Asian Refugees in Canada. Canadian Public Policy, 26(3), pp. 311-330.

Beiser, M. (2005b). The Health of Immigrants and Refugees in Canada. Canadian Journal of Public Health, 96(supplement), pp. S30-S41.

Beiser, M. \& Stewart, M. (2005b). Reducing Health Disparities: A Priority for Canada. Canadian Journal of Public Health, 96(supplement), pp. S4-S5.

Blais, R. \& Maiga, A. (1999). Do ethnic groups use health services like the majority population? A study from Quebec, Canada. Social Science and Medicine, 48(9), pp. 1237-1245.

Boyd, M. (1994). Canada's Refugee Flows: Gender Inequality. Canadian Social Trends, 32(7), p.12.

Browne, A. (2004). Healthcare Reform in Canada: The Romanow Report. Special Section: International Voices, 13(3), pp. 221-225.

Calliste, A. M. \& Dei, G. J. S. (Eds.) (2000). Anti-racist feminism: critical race and gender studies. Halifax: Fernwood Publishing.

Cannon, M. (1995). The Invisible Empire: Racism in Canada. Toronto, ON: Random House.

Cashman, S. B., Savageau, J. A., Lemay, C. A., \& Ferguson, W. (2004). Patient Health Status and Appointment Keeping in an Urban Community Health Centre. Journal of Health Care for the Poor and Underserved, 15(3), pp. 474-488.

Chen, J., Hou, F., Sanmartin, C., Houle, C. Tremblay, S. \& Berthelot, J. M. (2002). Unmet Health Care Needs. Canadian Social Trends, 11(8), pp. 1822.

Childs, P. \& Williams, R., J., P. (1997). An Introduction to Postcolonial Theory. England: Prentice Hall.

Citizenship and Immigration Canada. (2005). Annual Report to Parliament on Immigration 2005. Ministry of Public Works and Government Services Canada.

Cookson, S., Waldman, R., Gushlak, B., MacPherson, D., Burkle, F., Paquet, C., Kliewer, E., \& Walker, P. (1998). Immigrant and Refugee Health. Emerging Infectious Diseases, 4(3). Retrieved February 17, 2008 from the World Wide Web: http://www.cdc.gov/ncidod/eid/vol4no3/cookson.htm

Cooper, L. \& Freeland, R. (2007). The personal is political: health care in Canada. Social Work \& Society Online News Magazine. Retrieved 
February 17, 2008 from the World Wide Web:

http://www.socmag.net/?p=29

Courtenay, W. H. (2000a). Constructions of masculinity and their influence on men's well being: a theory of gender and health. Social Science and Medicine, 50(10), pp. 1985-1401.

Courtenay, W. (2004b). Making healthy manly: social marketing and men's health. The Journal of Men's Health and Gender, 1(2-3), pp. 275-276.

Dauvergne, Catherine (2005). Humanitarianism, Identity and Nation: Migration Law in Canada and Australia. Vancouver: UBC Press.

Deber, R. B., Forget, E. L., \& Roos, L. L. (2004). Medical Savings Accounts in a Universal System: Wishful Thinking Meets Evidence. Health Policy, 70(1), pp. 49-66.

Dench, J. (2006). Ending the Nightmare: Speeding up Refugee Family Reunification. In M. VanderPlaat (Ed.), "Immigration and Families/L'immigration et les Familles", Canadian Issues/ Themes Canadiens (pp.53-56). Montreal: Association for Canadian Studies.

Dominelli, L. (2002). Anti-Oppressive Social Work Theory and Practice. New York: Palgrave Macmillan.

Douglas, D. (2004). Immigrant Women and Health - OCASI Presentation. Retrieved February 16, 2008 from the World Wide Web: http://www.ocasi.org/index.php?qid=785\&catid=151

Dunn, J. R. \& Dyck, I. (2000). Social determinants of health in Canada's immigrant population: results from the National Population Health Survey. Social Science and Medicine, 51(11), pp. 1573-1593.

Forget, E. L., Deber, R. B., Roos, L. L., \& Walld, R. (2005). Canadian Health Reform: A Gender Analysis. Feminist Economics, 11(1), pp. 123-141.

Fowler, N. (1998). Providing primary healthcare to immigrants and refugees: the North Hamilton experience. Canadian Medical Association Journal, 159(4), pp. 388-391.

Frideres, J. (1993). Native Peoples in Canada: Contemporary Conflicts. Scarborough, ON: Prentice Hall.

Gabriel, G. (2006). A Question of Skills: Gender, Migration Policy and the Global Political Economy. In K. Vander Pijl, L. Assassi \& D. Wigen (Eds.), Global Regulation: Managing Crises After the Imperial Turn. Palgrave Macmillan.

Galabuzi, Grace-Edward (2001). Canada's Creeping Economic Apartheid: The Economic Segregation and Social Marginalization of Racial Groups. Centre for Social Justice Foundation for Research and Education. Retrieved May 27, 2007 from the World Wide Web: 
http://action.web.ca/home/narcc/attach/Canada\%5C\%27s\%20Creeping\% 20Economic\%20Apartheid.pdf

Gatrell, A. C. (2002). Geographies of Health. Massachusetts: Blackwell Publishers.

George, U. (2001). Toward Anti-Racism in Social Work in the Canadian Context. In A. M. Calliste \& G. J. S. Dei (Eds.), Anti-racist feminism: critical race and gender studies (pp. 111-122). Halifax: Fernwood Publishing.

Goldstein, J. \& Whitworth, S. (2005). International Relations (Canadian Edition). Toronto: Pearson-Longman.

Grace, S., Strong-Boag, V., Anderson, J. \& Eisenberg, A. (1998). Constructing Canada: An Introduction. In V. Strong-Boag, S. Grace, A. Eisenberg \& J. Anderson (Eds.). Painting the Maple: Essays on Race, Gender, and the Construction of Canada. Vancouver: UBC Press, pp. 3-15.

Hardiman, R. \& Jackson, B. W. (1997). Conceptual Foundations for Socila Justice Courses, Teaching for Diversity and Social Justice. New York: Routledge.

Hausmann-Muela, S., Ribera, J. M. \& Nyamongo, I. (2003). Health-seeking behaviour and the health system response. Disease Control Priorities Project Working Paper No. 4. Retrieved May 12, 2008 from the World Wide Web: http://www.dcp2.org/file/29/wp14.pdf

Hegre, H., Ostby, G. \& Raleigh, C. (2007). Economic Deprivation and Civil War Events: A Disaggregated Study of Liberia. Paper presented at the annual meeting of the American Political Science Association. Retrieved May 12, 2008 from the World Wide Web: http://www.allacademic.com/ meta/p210302_index.html

Kelley, N. \& Trebilcock, M. (1998). The Making of the Mosaic: A History of Canadian Immigration Policy. Toronto: University of Toronto Press.

Kemp, C. \& Rasbridge, L. A. (2004). Refugee and Immigrant Health: A Handbook for Health Professionals. New York: Cambridge University Press.

Khan, K. B., McDonald, H., Baumbusch, J. Kirkham, S. R., Tan, E. \& Anderson, J. (2007). Taking up postcolonial feminism in the field: Working through a method. Women's Studies International Forum, 30(3), pp. 228-242.

Lacroix, M. (2004). Canadian Refugee Policy and the Social Construction of the Refugee Claimant Subjectivity: Understanding Refugeeness. Journal of Refugee Studies, 17(2), pp. 147-166.

Lasser, K. E., Himmelstein, D. \& Woolhandler, S. (2006). Access to Care, Health Status, and Health Disparities in the United States and Canada: Results of a Cross-National Population-Based Survey. American Journal of Public Health, 96(7), pp. 1300-1307. 
Lynam, M. J., Henderson, A., Browne, A., Smye, V., Semeniuk, P., Blue, C., Singh, S., \& Anderson, J. (2003). Healthcare Restructuring with a View to Equity and Efficiency: Reflections on Unintended Consequences. Nursing Leadership, 16(1), pp. 112-140.

Macnaughton, N. S. (2008). Health Disparities in Health-Seeking Behaviour Among Latino Men: A Review of the Literature. Journal of Transcultural Nursing, 19(1), pp. 83-91.

Malmberg, G. (1997). Time and Space in International Migration. In T. Hammer, G. Brochmann, K. Tamas \& T. Faist (Eds.). International Migration, Immobility and Development: Multidisciplinary Perspectives. Oxford, U.K.: Berg Publishers.

Meade, M. S. \& Earickson, R. J. (2000). Medical Geography (2 ${ }^{\text {nd }}$ Ed.). New York: The Guilford Press.

McGregor, S. L.T. (2001). Neoliberalism and health care. International Journal of Consumer Studies - Special Edition on 'Consumers and Health', 25(2), pp. 82-89.

Mullaly, B. (2002a). Challenging Oppression: A Critical Social Work Approach. Don Mills: Oxford University Press.

Mullaly, B. (2007b). Oppression: The focus of structural social work. In B. Mullaly (Ed.), The new structural social work (pp. 252-286). Don Mills: Oxford University Press.

Equality Fact Sheet \#4. (2003). Racial Inequality in Access to Work and Incomes. National Union of Public and General Employees. Retrieved May 15, 2008 from the World Wide Web:

http://www.nupge.ca/publications/equality/equality_fact_4.pdf

Newbold, K. B., Eyles, J., Birch, S. \& Spencer, A. (1998a). Allocating Resources in Health Care: Alternative Approaches to Measuring Needs in Resource Allocation Formula in Ontario. Health and Place, 4(1), pp. 79-89.

Newbold, K. B. (2005b). Self-rated health within the Canadian immigrant population: risk and the healthy immigrant effect. Social Science and Medicine, 60(6), pp. 1359-1370.

Nghe, L. T., Mahalik, J. R. \& Lowe, S. M. (2003). Influences on Vietnamese Men: Examining Traditional Gender Roles, the Refugee Experience, Acculturation, and Racism in the United States. Journal of Multicultural Counselling and Development, 31(10), pp. 245-259.

Pavlish, C. (2007). Narrative inquiry into life experiences of refugee women and men. International Nursing Review, 54(1), pp. 28-34. 
Perez, C. E. (2002). Health status and health behaviour among immigrants. Statistics Canada, Catalogue 82-003, Supplement to Health Reports (13), pp. 89-101.

Pickwell, S. M. (1999). Multilevel Healing Pursuits of Cambodian Refugees. Journal of Immigrant Health, 1(3), pp. 165-179.

Plouffe, L. A. (2003). Addressing social and gender inequalities in health among seniors in Canada. Opinion, 19(3), pp. 855-860.

Pottie, K., Brown, J. B., \& Dunn, S. (2005). The Resettlement of Central American Men in Canada: From Emotional Distress to Successful Integration. Refuge, 22(2), pp. 101-111.

Preamble to the Constitution of the World Health Organization as adopted by the International Health Conference, New York, 19-22 June, 1946 by the representatives of 61 States (Official Records of the World Health Organization, no. 2, p. 100) and entered into force on 7 April 1948. Retrieved February 16, 2008 from the World Wide Web: http://www.who.int/about/definition/en/print.html

Ricketts, T. C. \& Goldsmith, L. J. (2005). Access in health service research: The battle of the frameworks. Nursing Outlook, 53(6), pp. 274-280.

Schweitzer, R., Melville, F., Steel, Z., \& Lacherez, P. (2006). Trauma, postmigration living difficulties, and social support as predictors of psychological adjustment in resettled Sudanese refugees. Australian and New Zealand Journal of Psychiatry, 40(2), pp. 179-187.

Simich, L., Beiser, M., Stewart, M. \& Mwakarimba, E. (2005). Providing Social Support for Immigrants and Refugees in Canada: Challenges and Directions. Journal of Immigrant Health, 7(4), pp. 259-267.

Spitzer, D. L. (2005). Engendering Health Disparities. Canadian Journal of Public Health, 96(supplement), pp. S78-S91.

Stampino, V. G. (2007). Improving access to multilingual health information for newcomers to Canada. Journal of the Canadian Health Libraries Association, 28(3), pp. 15-18.

Statistics Canada. (2001a). Health Care/Self-Care. Health Reports, 12(3), pp. 3339.

Statistics Canada. (2007b). Study: Canada's Immigrant labour market. The Daily. Retrieved October 25, 2007, from the World Wide Web: http://www.statcan.ca/Daily/English/070910/d070910a.htm

Steele, L. S., Lemieux-Charles, L., Clark, J. P., \& Glazier, R. H. (2002). The impact of policy changes on the health of recent immigrants and refugees in the inner city: A qualitative of service providers' perspectives. Canadian Journal of Public Health, 93(2), pp.118-122. 
Stewart, J., Miriam (2003). Immigrants and Refugees: Perspectives on Supportive Policies, Programs, and Practices. Prairie Centre of Excellence for Research in Immigration and Integration. Retrieved November 9, 2007 from the World Wide Web: http://pcerii.metropolis.net/ViennaConference/stewart.pdf

Thobani, S. (2000). Closing ranks: racism and sexism in Canada's Immigration Policy. Race \& Class, 42(1), pp. 35-55.

Tolentino, R. B. (1996). Bodies, Letter, Catalogs: Filipinas in Transnational Space. Social Text, 14(3), pp. 49-76.

United Nations High Commissioner for Refugees. (2000a). Statistics and Registration: A Progress Report. Retrieved May 15, 2008 from the World Wide Web: http://www.unhcr.org/statistics.html

United Nations High Commissioner for Refugees. (2005b). Global Refugee Trends. Retrieved June 12, 2008 from the World Wide Web: http://www.unhcr.org/protect.html

United Nations Population Fund. (2005). International Migration Report 2005. Retrieved November 4, 2007 from the World Wide Web: http://www.unfpa.org/swp/2005/presskit/message1.htm

Ontario Coalition Against Poverty. (2004). What is a Don't Ask Policy. Retrieved August 25, 2008 from the World Wide Web: http://www.ocap.ca/immigration/dontask.html

Ontario Council of Agencies Serving Immigrants. (2005). Canada's Health Care Debate- The Impact on Newcomers. Retrieved August 20, 2008 from the World Wide Web:

http://www.ocasi.org/downloads/OCASI_health_care_policy_position.pdf

Omidvar, R. \& Richmond, T. (January, 2003). Perspectives on Social Inclusion: Immigration Settlement and Social Inclusion in Canada. The Laidlaw Foundation. Retrieved January 12, 2008 from the World Wide Web: http://www.laidlawfdn.org/files/children/richmond.pdf

Williams, D. P. \& Hampton, A. (2005). Barriers to Health Services Perceived by Marshallese Immigrants. Journal of Immigrant Health, 7(4), pp. 317-326.

Yee, J. (2005). Critical anti-racist praxis: The concept of whiteness implicated. In S. Hick, J. Fook \& R. Pozzuto (Eds.), Social work, a critical turn (pp. 87104). Toronto: Thompson

Yu, S., Ouellet, E. \& Warmington, A. (2007). Refugee Integration in Canada: A Survey of Empirical Evidence and Existing Services. Refuge, 24(2), pp. 1734. 